\title{
PENGARUH PROFITABILITAS, SIZE TERHADAP NILAI PERUSAHAAN DENGAN SRUKTUR MODAL SEBAGAI VARIABEL INTERVENING
}

\author{
Sri Hermuningsih \\ Fakultas Ekonomi, Universitas Sarjanawiyata Tamansiswa Yogyakarta \\ e-mail: hermun_feust@yahoo.co.id
}

\begin{abstract}
This study investigates the impact of profitability and firm size on firm value with capital structure as an intervening variable of Indonesian public listed firms over the period of 2006 to 2010. Using panel data and Structural Equation Model analysis, this study finds that profitability has negative influence on capital structure, with a significance value 0.023. Second, firm size has positive influence on capital structure with a significance value 0.012. Third, capital structure has positive influence on firm size with a significance value 0.000. Fourth, profitability and firm size have indirect effect on firm value with capital structure as an intervening variable.
\end{abstract}

Keywords: profitability, firm size, capital structure, firm value.

\begin{abstract}
Abstrak
Studi ini mengkaji dampak profitabilitas dan ukuran perusahaan terhadap nilai perusahaan dengan struktur modal sebagai variabel intervening pada perusahaan tercatat di Bursa Efek Indonesia selama periode 2006 sampai dengan 2010. Menggunakan panel data dan Analsis Structural Equation Model, penelitian ini menemukan bahwa profitabilitas berpengaruh negatif terhadap struktur modal, dengan nilai signifikansi 0,023. Kedua, ukuran perusahaan berpengaruh positif terhadap struktur modal dengan nilai signifikansi 0,012. Ketiga, struktur modal berpengaruh positif terhadap ukuran perusahaan dengan nilai signifikansi 0,000. Keempat, profitabilitas dan ukuran perusahaan memiliki pengaruh tidak langsung terhadap nilai perusahaan dengan struktur modal sebagai variabel intervening.
\end{abstract}

Kata kunci: profitabilitas, ukuran perusahaan, struktur modal, nilai perusahaan.

\section{PENDAHULUAN}

Kondisi perekonomian saat ini telah menciptakan suatu persaingan yang ketat antar perusahaan dalam industri. Persaingan membuat setiap perusahaan semakin meningkatkan kinerja agar tujuannya dapat tetap tercapai. Tujuan utama perusahaan yang telah go public adalah meningkatkan kemakmuran pemilik atau para pemegang saham melalui peningkatan nilai perusahaan (Salvatore, 2005). Nilai perusahaan sangat penting karena mencerminkan kinerja perusahaan yang dapat mempengaruhi persepsi investor terhadap perusahaan. Nilai perusahaan merupakan nilai pasar dari suatu ekuitas perusahaan ditambah nilai pasar hutang. Dengan demikan, penambahan dari jumlah ekuitas perusahaan dengan hutang perusahaan dapat mencerminkan nilai perusahaan. Nilai perusahaan dapat menggambarkan keadaan perusahaan. Dengan baiknya nilai perusahaan maka perusahaan akan dipandang baik oleh para calon investor, demikian pula sebaliknya nilai Nilai pemegang saham akan meningkat apabila nilai perusahaan meningkat yang ditandai dengan tingkat pengembalian investasi yang tinggi kepada pemegang saham. Beberapa faktor yang dapat mempengaruhi nilai perusahaan adalah profitabilitas, size dan struktur modal.

Profitabilitas adalah kemampuan perusahaan memperoleh laba dalam hubungannya dengan penjualan, total aktiva maupun modal sendiri (Sartono, 2001). Perusahaan-perusahaan dengan profit yang tinggi cenderung menggunakan lebih banyak pinjaman untuk memperoleh manfaat pajak. Profitabilitas adalah rasio dari efektifitas manajemen berdasarkan hasil pengembalian yang dihasilkan dari penjualan 
dan investasi. Rasio profitabilitas terdiri atas profit margin, basic earning power, return on assets, dan return on equity. Weston dan Copeland (2008) mendefinisikan probabilitas sejauh mana perusahaan menghasilkan laba dari penjualan dan investasi perusahaan. Apabila profitabitas perusahaan baik maka para stakeholders yang terdiri dari kreditur, supplier, dan juga investor akan melihat sejauh mana perusahaan dapat menghasilkan laba dari penjualan dan investasi perusahaan. Dengan baiknya kinerja perusahaan akan meningkatkan pula nilai perusahaan (Suharli, 2006). Dalam penelitian yang dilakukan oleh Santika dan Kusuma (2002) pengaruh profitabilitas sebagai indikator kinerja perusahaan berpengaruh positif terhadap perusahaan. Karena dengan meningkatnya kinerja perusahaan akan meningkatkan ROA dan ROE yang merupakan contoh proksi dari rasio profitabilitas

Ukuran peusahaan (size) merupakan suatu indikator yang menunjukkan kekuatan finansial perusahaan. Ukuran perusahaan dianggap mampu mempengaruhi nilai perusahaan, karena semakin besar ukuran atau skala perusahaan maka akan semakin mudah pula perusahaan memperoleh sumber pendanaan baik yang bersifat internal maupun eksternal. Soliha dan Taswan (2002) menunjukkan bahwa ukuran perusahaan berpengaruh positif terhadap nilai perusahaan.

Struktur modal adalah proporsi pendanaan dengan hutang (debt financing) perusahaan, yaitu rasio leverage (pengungkit) perusahaan. Dengan demikian, hutang adalah unsur dari struktur modal perusahaan. Struktur modal merupakan kunci perbaikan produktivitas dan kinerja perusahaan. Teori struktur modal menjelaskan bahwa kebijakan pendanaan (financial policy) perusahaan dalam menentukan struktur modal (bauran antara hutang dan ekuitas) bertujuan untuk mengoptimalkan nilai perusahaan (value of the firm). Struktur modal yang optimal suatu perusahaan adalah kombinasi dari utang dan ekuitas (sumber eksternal) yang memaksimumkan harga saham perusahaan. Pada saat tertentu, manajemen perusahaan menetapkan struktur modal yang ditargetkan, yang mungkin merupakan struktur yang optimal, meskipun target tersebut dapat berubah dari waktu ke waktu. Sejumlah faktor mempengaruhi keputusan mengenai struktur modal perusahaan, seperti stabilitas penjualan, struktur aktiva, leverage operasi, peluang pertumbuhan, tingkat profitabilitas, pajak penghasilan, tindakan manajemen dan sebagainya. Faktor-faktor lain yang mempengaruhi struktur modal perusahaan adalah ukuran perusahaan, perusahaan yang lebih besar pada umumnya lebih mudah memperoleh pinjaman dibandingkan dengan perusahaan kecil. Oleh sebab itu dengan memperoleh pinjaman perusahaan dapat berkembang lebih baik lagi (Mai, 2006).

Tujuan yang ingin dicapai dalam penelitian ini adalah: (1) menguji pengaruh profitabilitas terhadap struktur modal. (2) menguji pengaruh sizeterhadap struktur Modal. (3) menguji pengaruh struktur modal terhadap nilai perusahaan. Hasil penelitian ini diharapkan dapat dijadikan bahan pertimbangan bagi investor dalam berinvestasi dan sebagai bahan pertimbangan bagi perusahaan dalam mengaplikasikan variabel-variabel penelitian ini untuk membantu meningkatkan nilai perusahaan serta sebagai bahan pertimbangan emiten untuk mengevaluasi, memperbaiki, dan meningkatkan kinerja manajemen keuangan dimasa mendatang.

\section{KAJIAN PUSTAKA}

\section{Nilai Perusahaan}

Nilai perusahaan sangat penting karena dengan nilai perusahaan yang tinggi akan diikuti oleh tingginya kemakmuran pemegang saham (Bringham dan Houston, 2006), Semakin tinggi harga saham semakin tinggi pula nilai perusahaan. Nilai perusahaan yang tinggi menjadi keinginan para pemilik perusahaan, sebab dengan nilai yang tinggi menunjukan kemakmuran pemegang saham juga tinggi. Kekayaan pemegang saham dan perusahaan dipresentasikan oleh harga pasar dari saham yang merupakan cerminan dari keputusan investasi, pendanaan (financing), dan manajemen asset.

Harga pasar dari saham perusahaan yang terbentuk antara pembeli dan penjual disaat terjadi transaksi disebut nilai pasar perusahaan, karena harga pasar saham dianggap cerminan dari nilai aset perusahaan sesungguhnya. Nilai perusahaan yang dibentuk melalui indikator nilai pasar saham sangat dipengaruhi oleh peluang-peluang investasi. Adanya peluang investasi dapat memberikan sinyal positif tentang pertumbuhan perusahaan 
dimasa yang akan datang, sehingga dapat meningkatkan nilai perusahaan.

\section{Faktor-Faktor yang Mempengaruhi Nilai Perusahaan \\ Profitabilitas}

Profitabilitas merupakan kemampuan suatu perusahaan untuk mendapatkan laba (keuntungan) dalam suatu periode tertentu. Pengertian yang sama disampaikan oleh Husnan (2001) bahwa Profitabilitas adalah kemampuan suatu perusahaan dalam menghasilkan keuntungan (profit) pada tingkat penjualan, aset, dan modal saham tertentu. Profitabilitas menggambarkan kemampuan badan usaha untuk menghasilkan laba dengan menggunakan seluruh modal yang dimiliki. Profitabilitas suatu perusahaan akan mempengaruhi kebijakan para investor atas investasi yag dilakukan. Kemampuan peurusahaan untuk menghasilkan laba akan dapat menarik para investor untuk menanamkan dananya guna memperluas usahanya, sebaliknya tingkat profitabilitas yang rendah akan menyebabkan para investor menarik dananya. Sedangkan bagi perusahaan itu sendiri profitabilitas dapat digunakan sebagai evaluasi atas efektivitas pengelolaan badan usaha tersebut.

Profitabilitas perusahaan merupakan salah satu dasar penilaian kondisi suatu perusahaan, untuk itu dibutuhkan suatu alat analisis untuk bisa menilainya. Alat analisis yang dimaksud adalah rasio-rasio keuangan. Ratio profitabilitas mengukur efektifitas manajemen berdasarkan hasil pengembalian yang diperoleh dari penjualan dan investasi. Profitabilitas juga mempunyai arti penting dalam usaha mempertahankan kelangsungan hidupnya dalam jangka panjang, karena profitabilitas menunjukkan apakah badan usaha tersebut mempunyai prospek yang baik di masa yang akan datang. Dengan demikian setiap badan usaha akan selalu berusaha meningkatkan profitabilitasnya, karena semakin tinggi tingkat profitabilitas suatu badan usaha maka kelangsungan hidup badan usaha tersebut akan lebih terjamin.

\section{Ukuran perusahaan (siz)}

Ukuran perusahaan adalah rata-rata total penjualan bersih untuk tahun yang bersangkutan sampai beberapa tahun. Dalam hal ini pen- jualan lebih besar daripada biaya variabel dan biaya tetap, maka akan diperoleh jumlah pendapatan sebelum pajak. Sebaliknya jika penjualan lebih kecil daripada biaya variabel dan biaya tetap maka perusahaan akan menderita kerugian (Brigham and Houston 2001). Keadaan yang dikehendaki oleh perusahaan adalah perolehan laba bersih sesudah pajak karena bersifat menambah modal sendiri. Laba operasi ini dapat diperoleh jika jumlah penjualan lebih besar daripada jumlah biaya variabel dan biaya tetap. Agar laba bersih yang diperoleh memiliki jumlah yang dikehendaki maka pihak manajemen akan melakukan perencanaan penjualan secara seksama, serta dilakukan pengendalian yang tepat, guna mencapai jumlah penjualan yang dikehendaki. Manfaat pengendalian manajemen adalah untuk menjamin bahwa organisasi telah melaksanakan strategi usahanya dengan efektif dan efisien.

Dalam aspek finansial, penjualan dapat dilihat dari sisi perencanaan dan sisi realisasi yang diukur dalam satuan rupiah. Dalam sisi perencanaan, penjualan direfleksikan dalam bentuk target yang diharapkan dapat direalisir oleh perusahaan. Perusahaan dengan ukuran yang lebih besar memiliki akses yang lebih besar untuk mendapat sumber pendanaan dari berbagai sumber, sehingga untuk memperoleh pinjaman dari krediturpun akan lebih mudah karena perusahaan dengan ukuran besar memiliki probabilitas lebih besar untuk memenangkan persaingan atau bertahan dalam industri. Pada sisi lain, perusahaan dengan skala kecil lebih fleksibel dalam menghadapi ketidakpastian, karena perusahaan kecil lebih cepat bereaksi terhadap perubahan yang mendadak. Oleh karena itu, memungkinkan perusahaan besar tingkat leveragenya akan lebih besar dari perusahaan yang berukuran kecil.

\section{Sruktur modal}

Struktur modal adalah perimbangan atau perbandingan antara jumlah hutang jangka panjang dengan modal sendiri. Oleh karena itu, struktur modal diukur dengan debt to equity ratio (DER). DER merupakan rasio yang digunakan untuk mengukur tingkat leverage (penggunaan hutang) terhadap total shareholder's equity yang dimiliki perusahaan. Total debt merupakan total liabilities (baik hutang jangka pendek maupun jangka panjang) sedangkan 
total shareholder's equity merupakan total modal sendiri (total modal saham yang disetor dan laba yang ditahan) yang dimiliki perusahaan. Rasio ini menunjukkan komposisi atau struktur modal dari total pinjaman (hutang) terhadap total modal yang dimiliki perusahaan. Semakin tinggi DER menunjukkan komposisi total hutang (jangka pendek dan jangka panjang) semakin besar dibandingkan dengan total modal sendiri, sehingga berdampak semakin besar beban perusahaan terhadap pihak luar (kreditur).

Selain teori yang telah dikemukakan oleh MM masih terdapat teori struktur modal yang lain yang membahas hubungan antara struktur modal dengan nilai perusahaan. Model trade-off mengasumsikan bahwa struktur modal perusahaan merupakan hasil trade-off dari keuntungan pajak dengan menggunakan hutang dengan biaya yang akan timbul sebagai akibat penggunaan hutang tersebut. Esensi trade-off theory dalam struktur modal adalah menyeimbangkan manfaat dan pengorbanan yang timbul sebagai akibat penggunaan hutang. Sejauh manfaat lebih besar, tambahan hutang masih diperkenankan. Apabila pengorbanan karena penggunaan hutang sudah lebih besar, maka tambahan hutang sudah tidak diperbolehkan. Trade-off theory telah mempertimbangkan berbagai faktor seperti corporate tax, biaya kebangkrutan, dan personal tax, dalam menjelaskan mengapa suatu perusahaan memilih struktur modal tertentu (Husnan, 2000). Kesimpulannya adalah penggunaan hutang akan meningkatkan nilai perusahaan tetapi hanya pada sampai titik tertentu. Setelah titik tersebut, penggunaan hutang justru menurunkan nilai perusahaan. Walaupun model tradeoff theory tidak dapat menentukan secara tepat struktur modal yang optimal, namun model tersebut memberikan kontribusi penting yaitu; 1) Perusahaan yang memiliki aktiva yang tinggi, sebaiknya menggunakan sedikit hutang. 2) Perusahaan yang membayar pajak tinggi sebaiknya lebih banyak menggunakan hutang dibandingkan perusahaan yang membayar pajak rendah.

\section{Pengembangan Hipotesis}

\section{Pengaruh profitabilitas dan sruktur modal}

Profitabilitas adalah kemampuan perusahaan memperoleh laba dalam hubungannya dengan penjualan, total aktiva maupun modal sendiri (Sartono, 2001). Definisi lain menurut Mai (2006), profitabilitas merupakan kemampuan perusahaan untuk memperoleh laba. Perusahaan-perusahaan dengan profit yang tinggi cenderung menggunakan lebih banyak pinjaman untuk memperoleh manfaat pajak. Hal ini karena pengurangan laba oleh bunga pinjaman akan lebih kecil dibandingkan apabila perusahaan menggunakan modal yang tidak dikenai bunga, namun penghasilan kena pajak akan lebih tinggi (Mai, 2006).

Keputusan pendanaan yang dilakukan secara tidak cermat akan menimbulkan biaya tetap dalam bentuk biaya modal yang tinggi, yang selanjutnya dapat berakibat pada rendahnya profitabilitas perusahaan (Kartini dan Arianto, 2008). Dengan kata lain, keputusan pendanaan atau struktur modal sangat berpengaruh terhadap rendah atau tingginya profitabilitas suatu perusahaan. Menurut pecking order theory, perusahaan dengan tingkat keuntungan yang besar memiliki sumber pendanaan internal yang lebih besar dan memiliki kebutuhan untuk melakukan pembiayaan investasi melalui pendanaan eksternal yang lebih kecil (Schoubben and Van Hulle, 2004; Adrianto dan Wibowo, 2007). Dengan demikian, teori ini memprediksikan profitabilitas berpengaruh negatif terhadap struktur modal. Berdasarkan pernyataan tersebut, maka dapat dirumuskan hipotesis sebagai berikut. Berdasarkan uraian tersebut, dapat dirumuskan hipotesis dalam penelitian ini sebagai berikut:

$\mathrm{H}_{1}$ : Profitabilitas berpengaruh negatif terhadap struktur modal.

\section{Pengaruh ukuran perusahaan (size) ter- hadap sruktur modal}

Menurut Kartini dan Arianto (2008) ukuran perusahaan merupakan salah satu faktor yang dipertimbangkan dalam menentukan berapa besar kebijakan keputusan pendanaan (struktur modal) dalam memenuhi ukuran atau besarnya asset perusahaan. Perusahaan pada pertumbuhan yang tinggi akan selalu membutuhkan modal yang semakin besar demikian juga sebaliknya perusahan pada pertumbuhan penjualan yang rendah, kebutuhan terhadap modal juga semakin kecil maka, konsep tingkat pertumbuhan penjualan tersebut memiliki hubung- 
an yang positif tetapi implikasi tersebut akan memberikan efek yang berbeda terhadap struktur modal yaitu dalam penentuan jenis modal yang digunakan.

Perusahaan yang berada pada pertumbuhan penjualan yang tinggi membutuhkan dukungan sumber daya organisasi (modal) yang semakin besar, demikian juga sebaliknya, pada perusahaan yang tingkat pertumbuhan penjualannya rendah kebutuhan terhadap sumber daya organisasi (modal) juga semakin kecil. Jadi konsep tingkat pertumbuhan penjualan tersebut memiliki hubungan yang positif, tetapi implikasi tersebut dapat memberikan efek yang berbeda terhadap struktur modal yaitu dalam penentuan jenis modal yang akan digunakan. Apabila perusahaan dihadapkan pada kebutuhan dana yang semakin meningkat akibat pertumbuhan penjualan, dan dana dari sumber intern sudah digunakan semua, maka tidak ada pilihan lain bagi perusahaan untuk menggunakan dana yang berasal dari luar perusahaan, baik hutang maupun dengan mengeluarkan saham baru.

Pada perusahan yang besar di mana saham akan tersebar luas, setiap perluasan modal saham akan mempunyai pengaruh yang kecil terhadap terhadap hilangnya atau tergesernya pengendalian dari pihak yang dominan terhadap pihak yang bersangkutan (Riyanto, 2001). Sebaliknya perusahaan yang kecil dimana saham tersebut berada dilingkungan perusahan yang kecil, penambahan jumlah saham akan mempunyai pengaruh yang besar terhadap kemungkinan kontrol pihak dominan terhadap perusahaan yang bersangkutan. Perusahaan dengan ukuran yang lebih besar memiliki akses untuk mendapatkan sumber pendanaan dari berbagai sumber sehingga untuk mendapat pinjaman dari kreditur akan lebih mudah karena perusahaan dengan ukuran besar memiliki probabilitas lebih besar untuk memenangkan persaingan dalam industri, sebaliknya perusahaan dengan skala kecil akan lebih menghadapi ketidakpastian, karena perusahaan kecil lebih cepat bereaksi terhadap perubahan yang mendadak. Oleh karena itu, memungkinkan perusahaan besar tingkat leverage akan lebih besar dari pada perusahaan yang berukuran kecil. Dari uraian yang telah dipaparkan, dapat disimpulkan bahwa besar kecilnya (ukuran) perusahaan akan berpengaruh terhadap struktur modal dengan didasarkan pada kenyataan bahwa semakin besar suatu perusahaan mempunyai tingkat pertumbuhan penjualan yang tinggi sehingga perusahaan tersebut akan lebih berani mengeluarkan saham baru dan kecenderungan untuk menggunakan jumlah pinjaman juga semakin besar pula.

Berdasarkan uraian tersebut, dapat dirumuskan hipotesis dalam penelitian ini sebagai berikut:

$\mathrm{H}_{2}$ : Size berpengaruh positif terhadap struktur modal

\section{Pengaruh struktur modal terhadap nilai perusahaan}

Modigliani dan Miller (1958), menunjukkan bahwa nilai suatu perusahaan tidak dipengaruhi oleh struktur modal, bukti tersebut dengan berdasarkan serangkaian asumsi antara lain, tidak ada biaya broker (pialang), tidak ada pajak, tidak ada kebangkrutan, para investor dapat meminjam dengan tingkat suku bunga yang sama dengan perseroan, semua investor mempunyai informasi yang sama, EBIT tidak dipengaruhi oleh biaya hutang. Hasil tersebut menunjukkan kondisi-kondisi dimana struktur modal tidak relevan, MM juga memberikan petunjuk agar srtuktur modal menjadi relevan sehingga akan mempengaruhi nilai. Solihah dan Taswan (2002) dalam penelitiannya menunjukkan bahwa kebijakan hutang berpengaruh positif namun tidak signifikan terhadap nilai perusahaan. Driffield et., al. (2007) dalam penelitiannya menunjukkan bahwa adanya pengaruh yang signifikan untuk struktur kepemilikan terhadap leverage (DAR) dan nilai perusahaan (Tobin'Q) di Indonesia, Korea, Malaysia, dan tidak signifikan di Thailand. Penelitian yang dilakukan Syarif (2007) menemukan bahwa peningkatan hutang mampu meningkatkan nilai perusahaan.

Ekayana (2007), Sujoko dan Soebiantoro (2007) yang menemukan bahwa kebijakan hutang yang diukur dengan debt to equity ratio (DER) dan ukuran perusahaan yang diukur dengan total aset berpengaruh positif dan signifikan terhadap price book value (PBV). Berdasarkan uraian tersebut,dapat dirumuskan hipotesis dalam penelitian ini sebagai berikut:

$\mathrm{H}_{3}$ : Struktur Modal berpengaruh positif terhadap Nilai Perusahaan 


\section{METODE PENELITIAN}

\section{Populasi dan Sampel}

Populasi dalam penelitian ini adalah perusahaan yang masuk kategori LQ45 dan terdaftar di Bursa Efek Indonesia 2006-2010. Sedangkan pemilihan sampel dengan menggunakan metode purposive sampling. Sampel dipilih dengan kriteria sebagai berikut: 1) Perusahaan LQ45 yang terdaftar di Bursa Efek Indonesia (BEI) pada tahun 2006 sampai dengan tahun 2010. 2) Perusahaan bukan berupa industri keuangan (perbankan, sekuritas dan asuransi). 3) Menerbitkan laporan keuangan secara lengkap (laporan laba rugi, neraca) dengan perioda berakhir per 31 Desember, secara terus menerus sejak tahun 2006-2010. 4) Laporan keuangan perusahaan tidak mengalami kerugian selama tahun 2006 tahun 2010. 5) Saham perusahaan tetap aktif beroperasi hingga 31 Desember 2010.

\section{Sumber dan Data yang Digunakan}

Data yang digunakan dalam penelitian ini berupa data sekunder dan berupa data panel (atau time-series cross-sectional), yang terdiri dari: 1) Data laporan keuangan publikasi tahunan (annual report) periode 2006-2010. 2) Data transaksi harian dan bulanan berupa harga saham perusahaan sampel, return saham perusahaan sampel, indeks harga saham gabungan, return indeks harga saham gabungan dan return bebas risiko yang diproksikan dengan tingkat suku bunga Bank Indonesia. Pada penelitian ini diperoleh sampel sejumlah 180 perusahaan.

\section{Variabel dan Definisi Operasional}

\section{Variabel dependen}

\section{Nilai Perusahaan}

Nilai perusahaan diukur dengan Tobin'Q. Smithers dan Wright (2000) Tobin'Q memandingkan rasio nilai pasar saham perusahaan dengan nilai buku ekuitas perusahaan, dengan rumus:

$$
Q=\frac{(E M V+D)}{(E B V+D)}
$$

Dimana

$$
\begin{aligned}
& \mathrm{Q}=\text { Nilai Perusahaan. } \\
& \mathrm{D}=\text { Nilai buku dari total hutang. }
\end{aligned}
$$

$\mathrm{EMV}=$ Nilai Pasar dari Ekuitas.

$\mathrm{EBV}=$ Nilai buku dari Ekuitas.

EMV (Equity Market Value) diperoleh dari hasil perkalian harga sahm penutupan dengan jumlah saham yang beredar. EBV (Equity Bookt Value) diperoleh dari selisih total asset dengan total kewajiban.

\section{Variabel Independen}

\section{Profitabilitas}

Profitabilitas (X1) diukur dengan indikator sebagai berikut:

\section{$\mathrm{X} 1.1$ = Return On Equity (ROE)}

Rasio ini menunjukkan tingkat pengembalian yang dihasilkan manajemen atas modal yang ditanam oleh pemengang saham sesudah dipotong kewajiban kepada investor, dengan rumus sebagai berikut:

$$
R O E=\frac{\text { Laba bersih }}{\text { Modal sendiri }}
$$

\section{$\mathrm{X} 1.2$ = Return On Asset (ROA)}

Rasio ini menunjukkan hubungan antara tingkat keuntungan yang dihasilkan manajemen atas dana yang ditanam baik oleh pemegang saham maupun kreditir, dengan rumus sebagai berikut:

$$
R O A=\frac{\text { Laba bersih }}{\text { Total Aktiva }}
$$

\section{Ukuran perusahaan (size)}

Size (X2) diukur dengan indikator sebagai berikut:

Size $=$ Logarithm natural (Ln) of Total Assets

\section{Variabel Intervening}

\section{Struktur modal}

Struktur modal diukur dengan indikator sebagai berikut:

$$
\text { Struktur Modal }=\frac{\text { Total hutang }}{\text { Modal sendiri }}
$$

\section{Analisis data}

Teknik analisis data dalam penelitian menggunakan Structural Equation Modelling (SEM). Pengujian hipotesis penelitian ini menggunakan 
taraf signifikan 5\%, dengan menggunakan program Amos Versi 18. Adapun Persamaan Struktural, sebagai berikut:

Persamaan 1, pengaruh profitabilitas terhadap struktur modal:

StruktMod $=\beta_{1 \cdot 1}$.Profit $+\varepsilon_{1}$

Persamaan 2, pengaruh ukuran perusahaan terhadap struktur modal:

StruktMod $=\beta_{2 \cdot 2 .}$ Size $+\varepsilon_{2}$

Persamaan 3, pengaruh profitabilitas, ukuran perusahaan dan struktur modal terhadap nilai perusahaan:

Nilai Perusahaan $=\beta_{1 \cdot 1}$.Profit $+\beta_{2 \cdot 2 .}$ Size $+\beta_{3 \cdot 3}$

StruktMod $+\varepsilon_{3}$

Keterangan:

$\begin{array}{ll}\text { Profit } & =\text { Profitabilitas } \\ \text { Size } & =\text { Ukuran perusahaan } \\ \text { StruktMod } & =\text { Struktur Modal } \\ \varepsilon & =\text { Residual atas Nilai perusahaan }\end{array}$

\section{HASIL ANALISIS}

\section{Analisis Deskriptif}

Statistik deskriptif memberikan gambaran umum tentang objek penelitian yang dijadikan sampel. Pada tabel 1 dapat dilihat nilai maximum, minimum, rata-rata dan standar deviasi. Nilai minimum nilai perusahaan pada perusahaan yang masuk kategori LQ45 dan terdaftar di Bursa Efek Indonesia 2006-2010 sebesar $1 \%$, nilai tertinggi sebesar $6.424 \%$. Hal ini menunjukkan sebagian besar perusahaan LQ45 memiliki nilai perusahaan yang positif yang diukur dengan Tobin $Q$. Nilai rata-rata sebesar $1.206,54 \%$ dan standar deviasi sebesar $1.445,507 \%$ dimana nilai standar deviasi lebih besar dari nilai rata-ratanya. Kondisi ini menunjukkan adanya fluktuasi nilai perusahaan yang besar pada perusahaan manufaktur yang menjadi sampel.

Profitabilitas yang diukur dengan return on equity (ROE) nilai terendah sebesar $0,01 \%$ dan tertinggi sebesar $769 \%$, kondisi tersebut menunjukkan sebagian besar perusahaan LQ45 memiliki nilai profitabilitas yang positiff yang diukur dengan return on equity. Profitabilitas yang diukur dengan return on asset (ROA) nilai terendah sebesar $0,01 \%$ dan tertinggi sebesar $940 \%$, kondisi tersebut juga menunjukkan sebagian besar perusahaan LQ45 memiliki nilai profitabilitas yang positiff yang diukur dengan return on asset. Nilai rata-rata sebesar $50,39 \%$ dan standar deviasi sebesar $100,731 \%$ dimana nilai standar deviasinya lebih besar dari nilai rata-ratanya. Hal ini menunjukkan fluktuasi profitabilitas yang besar pada perusahaan LQ45 yang menjadi sampel.

Struktur Modal yang diukur dengan debt to equity ratio (DER) nilai terendah sebesar $0,01 \%$ dan tertinggi sebesar $65 \%$. Hal ini menunjukkan sebagian besar perusahaan LQ45 menggunakan hutang sebagai sumber pendanaannya. Nilai rata-rata sebesar $66,99 \%$ dan standar deviasi $92,751 \%$, dimana standar deviasinya lebih besar dari nilai rata-ratanya. Hal ini menunjukkan fluktuasi struktur modal yang besar pada perusahaan LQ45 yang menjadi sampel.

Size yang diukur dengan Ln Total aset nilai terendah sebesar $752 \%$ dan tertinggi sebesar $3.110 \%$. Nilai rata-rata sebesar $66,99 \%$ dan standar deviasi $92,751 \%$, dimana standar deviasinya lebih besar dari nilai rata-ratanya.

Hasil analisis SEM pada tahap akhir selengkapnya disajikan dalam bentuk analisis jalur sebagaimana tampak pada Gambar 2. Hasil Uji hipotesis dari gambar 2 dievaluasi berdasarkan goodness of fit pada tabel 2 dengan kriteria model serta nilai kitisnya yang memliki kesesuaian data.

Dari evaluasi model yang diajukan menunjukkan bahwa evaluasi terhadap model terhadap konstruk secara keseluruhan ternyata dari berbagai kriteria sudah tidak terdapat pelanggaran kritis. Dengan demikian dapat disimpulkan bahwa model akhir penelitian sesuai dengan data penelitian, sehingga dapat dilakukan uji kesesuaian model selanjutnya.

Tabel 1: Statistik Deskriptif

\begin{tabular}{llrrrr}
\hline & N & \multicolumn{1}{c}{ Minimum } & \multicolumn{1}{c}{ Maksimum } & \multicolumn{1}{c}{ Rata-rata } & Std. Deviation \\
\hline Nilai Perusahaan & 180 & 0,01 & 64,24 & 12,0654 & 14,45507 \\
ROE & 180 & 0,01 & 7,69 & 0,5039 & 1,00731 \\
ROA & 180 & 0,01 & 9,40 & 0,3992 & 1,21152 \\
Struktur Modal & 180 & 0,01 & 6,50 & 0,6699 & 0,92751 \\
Size & 180 & 7,52 & 31,10 & 20,8224 & 5,94482 \\
\hline
\end{tabular}




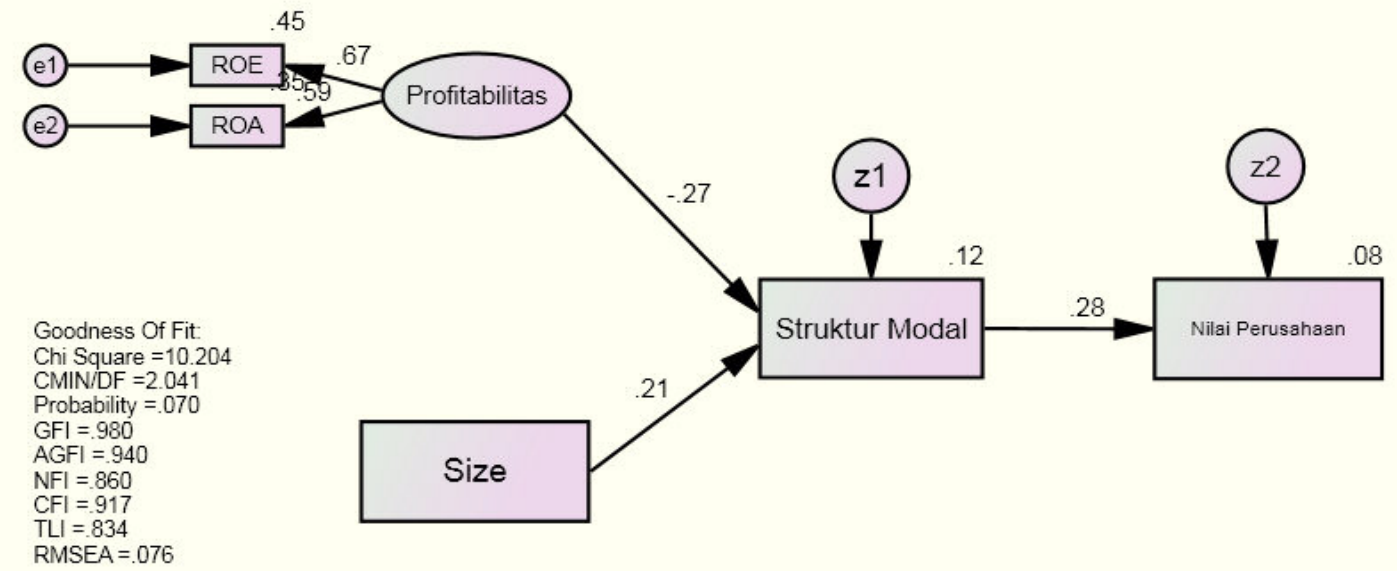

Gambar 2: Analisis jalur

Tabel 2: Kriteria Indeks Goodness of Fit

\begin{tabular}{llll}
\hline Goodness of Fit Index & Cut off Value & Hasil & Keterangan \\
\hline Chi square & Diharapkan kecil & 12,274 & Baik \\
Significance Probability & $\geq 0,05$ & 0,139 & Baik \\
RMSEA & $\leq 0,08$ & 0,055 & Baik \\
$G F I$ & $\geq 0,90$ & 0,980 & Baik \\
AGFI & $\geq 0,90$ & 0,947 & Baik \\
CMIN/DF/ $\chi^{2}$ relatif & $\leq 2,00$ & 1,534 & Baik \\
TLI & $\geq 0,95$ & 0,926 & Baik \\
CFI & $\geq 0,95$ & 0,960 & Baik \\
\hline
\end{tabular}

Sumber: Ghozali (2011)

Tabel 3: Hasil Pengujian Hipotesis

\begin{tabular}{llllll}
\hline Hipotesis & Variabel Independen & Variabel dependen & p-value & CR & Keterangan \\
\hline H1 & Profitabilitas & Struktur Modal & 0,023 & $-2,272$ & Signifikan \\
H2 & Size & Struktur Modal & 0,012 & 2,513 & Signifikan \\
H3 & Struktur Modal & Nilai Perusahaan & 0,000 & 3,515 & Signifikan \\
\hline
\end{tabular}

\section{Hasil Pengujian Hipotesis}

Pengujian hipotesis ini dengan menganalisis nilai CR dan nilai Probability hasil olah data, yaitu C.R $\geq 2,58$ atau $P<0,05$. Apabila hasil olah data menunjukkan nilai yang memenuhi syarat tersebut, maka hipotesis penelitian yang diajukan terbukti. Pada penelitian ini diajukan dua hipotesis dan pembahasan dengan menggunakan data pada Tabel 3 yang menunjukkan hasil uji hipotesis Analisis SEM. Hasil uji hipotesisi disajikan pada tabel 3.

\section{PEMBAHASAN}

Pengujian Hipotesisi 1 hasilnya menunjukkan nilai nilai C.R sebesar -2,272., p sebesar 0,023 lebih kecil dari 0.005 , artinya bahwa profitabilitas berpengaruh positif dan signifikan terhadap struktur modal. Hasil ini menunjukkan bahwa perusahaan-perusahaa besar yang profitable lebih cenderung bersifat konservatif menggunakan hutang untuk operasi perusahaannnya. Sementara untuk perusahaan yang kurang profitable cenderung tetap menggunakn dan internal telebih dahulu baru kemudian menutup kekurangannya degan melakukan peminjamanan dalam bentuk hutang. Perusahaan yang mempunyai Rate of return on investment (ROI) tinggi, menggunakan pendanaan relatif lebih kecil. Tingginya rate of return memungkinkan menggunakan pendanaan internal dari laba ditahan.Sebaliknya perusahaan yang mempunyai Rate of return on investment (ROI) rendah, cenderung tetap menggunakan sumber dana internal terlebih dulu baru kemudian menutup kekurangannya dengan melakukan pinjaman dalam bentuk hutang. 
Pengujian Hipotesisi 2 hasilnya menunjukkan nilai C.R sebesar 2,513, p sebesar 0,012 , artinya bahwa size berpengaruh positif dan signifikan terhadap struktur modal. Hal ini dapat dijelaskan bahwa besar kecilnya perusahaan sangat berpengaruh terhadap keputusan penggunaan hutang dalam struktur modal, terutama berkaitan dengan kemampuan memperoleh pinjaman. Perusahaan besar lebih terdiversifikasi, lebih mudah mengakses hutang di pasar modal dan menerima penilai kredit yang lebih tinggi untuk hutang-hutang yang diterbitkannya.

Pengujian Hipotesisi 3 hasilnya menunjukkan nilai C.R sebesar 3,515, p sebesar 0,001, artinya, bahwa struktur modal berpengaruh positif dan signifikan terhadap nilai perusahaan. Hal ini menunjukkan bahwa kebijakan penggunaan hutang dalam struktur modal memberikan suatu sinyal atau tanda bagi investor bahwa dengan kebujakan pendanaan oleh perusahaa mempengaruhi nilai perusahaan. Pengaruh struktur modal terhadap nilai perusahaan dikemukakan ole Lee dan Suk (1999), menemukan bahwa leverage (total liabilities to assets) berpengaruh positif terhadap market to book ratio.

\section{Pengaruh Profitabilitas, size terhadap nilai perusahaan dengan struktur modal sebagai variabel intervening}

Untuk melihat besarnya pengaruh langsung dan tidak langsung dapat dijelaskan dengan melihat besarnya nilai koefisien standardized beta sebagai berikut:

1) Pengaruh langsung profitabilitas terhadap struktur modal $=-0,263$ sung Profitabilitas terhadap nilai perusahaan melalui struktur modal Total pengaruh $=-\frac{-0,335 \times 0,334+}{=-0,37489}$

2) Pengaruh langsung size terhadap nilai perusahaan Pengaruh tidak langsung size terhadap nilai perusahaan melalui struktur modal

Total pengaruh $=\underline{0,354 \times, 334+}$
Berdasarkan hasil penelitian ini menunjukkan bahwa profitabilitas mempunyai pengaruh tidak langsung terhadap nilai perusahaan yang dapat dilihat dari hasil Total pengaruh menunjukkan bahwa koefisien estimate sebesar -0.37489. Sedangankan size mempunyai pengaruh tidak langsung terhadap nilai perusahaan yang dapat dilihat dari hasil Total pengaruh menunjukkan sebesar $-0,365236$. Hal ini berarti bahwa struktur modal merupakan variabel intervening bagi profitabilitas dan size yang mempengaruhi nilai perusahaan.

\section{PENUTUP}

Hasil penelitian ini menunjukkan. Pertama, profitabilitas berpengaruh positif dan signifikan terhadap struktur modal, hasil ini menunjukkan bahwa perusahaan-perusahaa besar yang profitable lebih cenderung bersifat konservatif menggunakan hutang untuk operasi perusahaannnya. Sementara untk perusahaan yang kurang profitable cenderung tetap menggunakan dan internal telebih dahulu baru kemudian menutup kekurangannya dengan melakukan peminjaman dalam bentuk hutang. Kedua, Size berpengaruh positif.dan signifikan terhadap struktur modal. Perusahaan besar lebih terdiversifikasi, lebih mudah mengakses hutang di pasar modal an menerima penilai kredit yang lebih tinggi untuk hutang-hutang yang diterbitkannya. Ketiga, struktur modal berpengaruh positif.dan signifikan terhadap nilai perusahaan. Hal ini menunjukkan bahwa kebijakan penggunaan hutang dalam struktur modal memberikan suatu sinyal atau tanda bagi investor bahwa dengan kebujakan pendanaan oleh perusahaa mempengaruhi nilai perusahaan.

Hasil penelitian tidak lepas dari beberapa kelemahan. Pertama, sampel hanya terbatas pada perusahaan yang masuk kategori LQ45. Kedua, variabel yang di gunakan hanya dua variabel profitabilitas dan size. Berdasarkan keterbatasan tersebut peneltian selanjutnya disarakan untuk memperbanyak sampel penelitian dan tidak hanya perusahaan LQ45 saja tetapi bisa perusahaan manufaktur atau perusahaan lainnya dan juga memperpanjang observasi agar supaya hasinya bisa di generalisasi. 


\section{DAFTAR PUSTAKA}

Adrianto dan Wibowo, B. 2007. Pengujian Teori Pecking Order pada PerusahaanPerusahaan Non Keuangan LQ45 Periode 2001-2005. Manajemen Usahawan Indonesia, XXXVI (12): 43-53.

Brigham, EF., and J. Houston. 2006. DasarDasar Manajemen Keuangan. Edisi Kesepuluh. Penerbit Salemba Empat, Jakarta.

Brigham, EF., dan LC Gapenski. 1993. Intermediet Financial and Management. Fourt Edition.

Driffeild, N., V. Mahambare, and S. Pal. 2007. How Does Ownership Structure Affect Capital Structure and Firm Value? Recent Evidence From East Asia. (online), (www.google.com).

Ekayana. 2007. Analisis Pengaruh Insider Ownership, Kebijakan Hutang, Profitabilitas dan Ukuran Perusahaan Terhadap Nilai Perusahaan (Studi Empiris Terhadap Perusahaan Manufaktur yang Terdaftar di Bursa Efek Jakarta tahun 2001-2005), ASET. 9 (2).

Ghozali, Imam. 2011. Analisis Multivariate SPSS, Badan Penerbit Universitas Diponegoro, Semarang.

Husnan, Suad. 2000. Manajemen Keuangan Teori dan Penerapan, Edisi Ketiga. Yogyakarta: UPP AMP YKPN.

Kartini dan A. Tulus. 2008. Struktur Kepemilikan, Profitabilitas, Pertumbuhan Aktiva dan Ukuran Perusahaan terhadap Struktur Modal pada Perusahaan Manufaktur, Jurnal Keuangan dan Perbankan, 12 (1). 11 - 21.

Mai, MU. 2006. Analisis Variabel-Variabel yang Mempengaruhi Struktur Modal Pada Perusahaan-Perusahaan LQ-45 di Bursa Efek Jakarta, Ekonomika, Hal. 228- 245. Politeknik Negeri, Bandung.

Modigliani, F. and MH. Miller. 1958. The cost of capital, corporation finance and the theory of investment. American Economic Review. 47(3): 261-297.
Riyanto, Bambang. 2001. Dasar-dasar Pembelanjaan Perusahaan. Yogyakarta BPFE.

Santika dan K. Ratnawati. 2002. Pengaruh Struktur Modal, Faktor Internal, Faktor Eksternal terhadap Nilai Perusahaan Industri yang Masuk Bursa Jakarta. Jurnal Bisnis Strategi, 10.

Sartono, Agus. 2001. Manajemen Keuangan: Teori dan Aplikasi, Edisi Keempat, Cetakan Pertama, BPFE, Yogyakarta.

Salvatore, Dominick. 2005. Ekonomi Manajerial dalam Perekonomian Global. Salemba Empat: Jakarta.

Schoubben, F., and Van Hulle, C. 2004. The Determinant of Leverage: Difference between Quoted and Non Quoted Firms. Tijdschrift voor Economie en Management. XLIX (4).

Soliha, E dan Taswan. 2002. Pengaruh Kebijakan Hutang Terhadap Nilai Perusahaan Serta Beberpa Faktor yang Mempengaruhinya. Jurnal Bisnis dan Ekonomi. (online), (www.google.com).

Smithers, Andrew dan Wright, Stephen. 2008. Valuing Wall Street, McGraw Hill.

Husnan., Suad. 2001. Dasa-dasar Teori Portfolio dan Analisis Sekuritas, Edisi Ketiga Yogyakarta.UPP AMP YKPN

Suharli, M. 2006. Studi Empiris Mengenai Pengaruh Profitabilitas, Leverage, Dan Harga Saham Terhadap Jumlah Dividen Tunai (Studi pada Perusahaan yang Terdaftar di Bursa Efek Jakarta Periode 2002-2003). Jurnal Manajemen, Akuntansi dan Sistem Informasi. 6 (2). 243-256.

Sujoko dan Subiantoro. 2007. Pengaruh Kepemilikan Saham, Laverage, Faktor Intern dan Faktor Ektern Terhadap Nilai Perusahaan (Studi Emperik Pada Perusahaan Manufaktur di Bursa Efek Jakarta). Jurnal Manajemen dan Kewirausahaan. 9 (1). 41-48.

Syarif F. 2007. Pengaruh Kebijakan Leverage, Kebijakan Deviden dan Earning Per Share Terhadap Nilai Perusahaan Manufaktur yang Terdaftar di Bursa 
Efek Indonesia. Jurnal Akuntansi 47. (online), (www.google.com).

Wahidahwati. 2002. Pengaruh Kepemlikan Manjerial dan Kepemilikan Institusional pada Kebijakan hutang Perusahaan: Sebuah Perspektif Theory
Agency. Jurnal Riset Akuntansi Indonesia. 5 (1). 1-16.

Weston, J. Fred dan Copeland, E. Thomas. 2008. Manajemen Keungan. Edisi Kesembilan, Penerbit Bina Aksara, Jakarta. 